\author{
KATARZYNA MAŁYSA-SULIŃSKA \\ ORCID: 0000-0002-6406-8851 \\ Uniwersytet Jagielloński \\ k.malysa-sulinska@uj.edu.pl
}

\title{
Władztwo planistyczne gminy a określanie sposobów zagospodarowania i warunków zabudowy terenu
}

\begin{abstract}
Abstrakt: W niniejszym artykule odniesiono się do władztwa planistycznego gminy, które nie jest nieograniczone i nie należy go pojmować jako pełnej swobody w zakresie określania przez gminę przeznaczenia terenu i zasad jego zagospodarowania. Decydowania o przeznaczeniu terenu i warunkach jego zabudowy ustawodawca nie pozostawił bowiem do wyłącznej kompetencji organów gminy, stanowiąc legitymację w tym zakresie także dla innych organów administracji publicznej. Nadto organy gminy — podejmując rozstrzygnięcia w ramach władztwa planistycznego — zostały przez ustawodawcę zobligowane do współdziałania z innymi organami. Analiza rozwiązań normatywnych odnoszących się do decyzji lokalizacyjnych wskazuje również, że organy gminy podejmując przedmiotowe rozstrzygnięcia nie dysponują w istocie swobodą planistyczną, a działają jedynie w ramach — zakreślonego przez prawodawcę — luzu decyzyjnego.
\end{abstract}

Słowa kluczowe: władztwo planistyczne gminy, określanie sposobów zagospodarowania i warunków zabudowy terenu, decyzja o ustaleniu lokalizacji inwestycji celu publicznego, decyzja o warunkach zabudowy.

\section{Wprowadzenie}

Wiodąc rozważania na temat istoty związków publiczno-prawnych, w tym gmin, Tadeusz Bigo zwracał uwagę między innymi na prowadzoną przez nie działalność i wskazywał, że cechuje ją wykorzystywanie środków niedostępnych dla 
osób prywatnych i ich zrzeszeń. W wyniku przeprowadzenia analizy środków prawnych, które mogły być stosowane przez gminy, Autor podniósł ich władczy charakter. Jednocześnie zauważył, że gmina dysponuje „władztwem, sięgającem daleko w sferę indywidualnych praw jej członków"1.

Powyższa konstatacja stała się przyczynkiem do napisania niniejszego artykułu, którego przedmiotem są aktualnie obowiązujące regulacje prawne w zakresie określania przez organy gminy sposobów zagospodarowania terenu i warunków jego zabudowy. Zgodnie bowiem z regulacją ujętą w art. 6 ust. 2 pkt 1 ustawy z dnia 27 marca 2003 roku o planowaniu i zagospodarowaniu przestrzennym ${ }^{2}$ (dalej: u.p.z.p.), każdy ma prawo, w granicach określonych przywołaną ustawą, do zagospodarowania terenu, do którego ma tytuł prawny, zgodnie z warunkami ustalonymi w miejscowym planie zagospodarowania przestrzennego albo decyzji o warunkach zabudowy i zagospodarowania terenu, jeżeli nie narusza to chronionego prawem interesu publicznego oraz osób trzecich. $Z$ rozwiązania przyjętego przez ustawodawcę w przepisach u.p.z.p. wynika, że treść - stanowionego przez radę gminy - miejscowego planu zagospodarowania przestrzennego lub - wydawanej przez wójta (burmistrza lub prezydenta miasta) — decyzji ustalającej warunki zabudowy i zagospodarowania terenu determinuje sposób wykonywania prawa własności nieruchomości. To zaś powoduje, że w literaturze wskazuje się, iż zakres władztwa planistycznego gminy jest szeroki, choć nie jest to władztwo nieograniczone ${ }^{3}$ i nie należy go rozumieć jako pełnej swobody w określaniu przez gminę przeznaczenia terenu i zasad jego zagospodarowania ${ }^{4}$.

Celem niniejszego artykułu jest zatem zakreślenie ram kompetencji organów gminy w przedmiocie określania przeznaczania terenu i warunków jego zabudowy, a nadto wskazanie zakresu swobody planistycznej, jaką jej organy dysponują $\mathrm{w}$ postępowaniach $\mathrm{z}$ tego zakresu. Zaznaczenia wymaga przy tym, że z uwagi na ograniczenia objętościowe niniejszego tekstu, przedmiot rozważań zasadniczo koncentruje się na kompetencji gminy do wydawania decyzji ustalających warunki zabudowy i zagospodarowania terenu, a regulacje odnoszące się do ustalania przeznaczenia terenu w miejscowych planach zagospodarowania przestrzennego stanowią wyłącznie tło dla prowadzonego dyskursu.

1 Zob. T. Bigo, Zwiazki publiczno-prawne w świetle ustawodawstw polskiego, Warszawa 1928, s. 59-60.

2 Dz.U. z 2021 r. poz. 741 ze zm.

3 Zob. M. Szewczyk, [w:] Z. Leoński, M. Szewczyk, M. Kruś, Prawo zagospodarowania przestrzeni, Warszawa 2019, s. 210-211.

4 Zob. Planowanie i zagospodarowanie przestrzenne. Komentarz, red. Z. Niewiadomski et al., Warszawa 2021, s. 23. 


\section{Władztwo planistyczne gminy jako zasada określania sposobów zagospodarowania i warunków zabudowy terenu na zasadach ogólnych}

W polskim systemie prawnym — jak wskazuje się w literaturze — zasadą jest władztwo planistyczne gminy, zwane również samodzielnością planistyczną gminy, rozumiane jako właściwość gminy w zakresie władczego określenia przeznaczania terenu i warunków jego zabudowy. Termin ten utożsamiany jest z ustawowym upoważnieniem organów gminy do ustalania przeznaczenia gruntów położonych na obszarze ich działania, a także określania sposobów ich zagospodarowania i warunków zabudowy ${ }^{5}$.

Sprawy z zakresu ładu przestrzennego zostały bowiem wskazane przez ustawodawcę jako zadania własne gminy ${ }^{6}$, przy czym normy kompetencyjne dla ich realizacji ujęto w przepisach przywołanej powyżej u.p.z.p. W ustawie tej zdefiniowano pojęcie ładu przestrzennego jako takie ukształtowanie przestrzeni, które tworzy harmonijną całość oraz uwzględnia w uporządkowanych relacjach wszelkie uwarunkowania i wymagania funkcjonalne, społeczno-gospodarcze, środowiskowe, kulturowe oraz kompozycyjno-estetyczne ${ }^{7}$. Nadto w akcie tym — co już zasygnalizowano powyżej — wskazano, że ustalenie przeznaczenia terenu, rozmieszczenie inwestycji celu publicznego oraz określenie sposobów zagospodarowania i warunków zabudowy terenu następuje w miejscowym planie zagospodarowania przestrzennego albo w decyzji o warunkach zabudowy i zagospodarowania terenu.

I tak zgodnie $\mathrm{z}$ regulacją ustawową w planach miejscowych ustala się przeznaczenie terenu, rozmieszczenie inwestycji celu publicznego oraz określa się sposoby zagospodarowania i warunki zabudowy terenu ${ }^{8}$. Wskazuje się w nich między innymi linie rozgraniczające tereny o różnym przeznaczeniu lub różnych zasadach zagospodarowania ${ }^{9}$, a także zasady kształtowania zabudowy oraz

5 Zob. ibidem, s. 21 n.; M. Szewczyk, op. cit., s. 208 n.; K. Małysa-Sulińska, Ramowe studium uwarunkowań i kierunków zagospodarowania przestrzennego związk metropolitalnego a władztwo planistyczne gminy, ,Ruch Prawniczy, Ekonomiczny i Socjologiczny” 2017, nr 3, s. 93 n.

6 Zob. art. 7 ust. 1 pkt 1 ustawy z dnia 8 marca 1990 roku o samorządzie gminnym, Dz.U. z 2020 r. poz. 713 ze zm.

7 Por. art. 2 pkt 1 u.p.z.p.

8 Zob. art. 4 ust. 1 u.p.z.p.

9 Por. art. 15 ust. 2 pkt 1 u.p.z.p Zob. też $\S 4$ pkt 1 rozporządzenia Ministra Infrastruktury z dnia 26 sierpnia 2003 roku w sprawie wymaganego zakresu projektu miejscowego planu zagospodarowania przestrzennego, Dz.U. Nr 164, poz. 1587 (w dalszej części przywoływane jako rozp.m.p.z.p.), zgodnie z którym — zawarte w projekcie tekstu miejscowego planu zagospodarowania przestrzennego - ustalenia dotyczące przeznaczenia terenów powinny zawierać określenie przeznaczenia poszczególnych terenów lub zasad ich zagospodarowania, a także symbol literowy i numer wyróżniający go spośród innych terenów. 
wskaźniki zagospodarowania terenu, maksymalną i minimalną intensywność zabudowy, minimalny udział procentowy powierzchni biologicznie czynnej, maksymalną wysokość zabudowy, minimalną liczbę miejsc do parkowania oraz linie zabudowy i gabaryty obiektów ${ }^{10}$. Miejscowe plany zagospodarowania przestrzennego są aktami prawa miejscowego ${ }^{11}$, co oznacza, że ustalenia w nich ujęte stanowią podstawę kształtowania władczych rozstrzygnięć w postępowaniach jurysdykcyjnych, czyli na przykład $\mathrm{w}$ decyzji o pozwoleniu na budowę ${ }^{12}$. W przypadku inwestycji lokalizowanych na zasadach ogólnych ${ }^{13}$ dany obszar może być bowiem zagospodarowany wyłącznie w sposób zgodny z ustaleniami obowiązującego planu miejscowego. Mając na uwadze powyższe, wskazać należy, że zasadą jest fakultatywne sporządzanie miejscowych planów zagospodarowania przestrzennego, a decyzje w tym zakresie podejmowane są przez radę gminy, czyli organ stanowiący jednostki samorządu lokalnego. Plan miejscowy sporządza się bowiem obowiązkowo wyłącznie wówczas, gdy wymagają tego przepisy ${ }^{14}$. Zauważenia wymaga przy tym, że — co do zasady — miejscowe plany zagospodarowania przestrzennego uchwalane są przez radę gminy. Jednakże ustawodawca stanowi odstępstwa od tej zasady wskazując, iż — przy zaistnieniu określonych przesłanek - plan miejscowy może zostać przyjęty w formie zarządzenia zastępczego wojewody ${ }^{15}$.

10 Por. art. 15 ust. 2 pkt 6 u.p.z.p. Zob. też $§ 4$ pkt 6 rozp.m.p.z.p., zgodnie z którym zawarte w projekcie tekstu miejscowego planu zagospodarowania przestrzennego ustalenia dotyczące parametrów i wskaźników kształtowania zabudowy oraz zagospodarowania terenu powinny zawierać w szczególności określenie linii zabudowy, wielkości powierzchni zabudowy w stosunku do powierzchni działki lub terenu, w tym udziału powierzchni biologicznie czynnej, a także gabarytów i wysokości projektowanej zabudowy oraz geometrii dachu.

11 Zob. art. 14 ust. 8 u.p.z.p.

12 Zob. art. 35 ust. 1 pkt 1 lit. a), ust. 4 i ust. 3 w zw. z ust. 5 pkt 1 ustawy z dnia 7 lipca 1994 roku. Prawo budowlane, Dz.U. z 2020 r. poz. 1333 ze zm.

13 Inne rozwiązania w tym zakresie przyjęto w specustawach inwestycyjnych (zob. np. art. 5 ust. 3 specustawy mieszkaniowej, w którym wskazano, że inwestycję mieszkaniową lub inwestycję towarzyszącą realizuje się niezależnie od istnienia lub ustaleń miejscowego planu zagospodarowania przestrzennego, pod warunkiem, że nie jest sprzeczna ze studium uwarunkowań i kierunków zagospodarowania przestrzennego gminy ani uchwałą o utworzeniu parku kulturowego).

14 Tak art. 14 ust. 7 u.p.z.p. Zob. np. art. 5 ust. 1 ustawy, zgodnie z którym gmina ma obowiązek sporządzenia miejscowego planu zagospodarowania przestrzennego dla obszaru Pomnika Zagłady i jego strefy ochronnej, przy czym — jak wskazano w art. 4 ust. 3 tej ustawy — granice tego obszaru i jego strefy ochronnej określa w rozporządzeniu minister właściwy do spraw kultury i ochrony dziedzictwa narodowego po zasięgnięciu opinii właściwego terytorialnie wójta (burmistrza lub prezydenta miasta).

15 Zob. art. 12 ust. 3 u.p.z.p., w którym wskazano, że jeżeli rada gminy nie uchwaliła studium, nie przystąpiła do jego zmiany albo, uchwalając studium, nie określiła w nim obszarów rozmieszczenia inwestycji celu publicznego o znaczeniu krajowym, wojewódzkim i metropolitalnym, ujętych w planie zagospodarowania przestrzennego województwa, wojewoda, po podjęciu czynności zmierzających do uzgodnienia terminu realizacji tych inwestycji i warunków wprowadzenia tych inwestycji do studium, wzywa radę gminy do uchwalenia studium lub jego zmiany w wyznaczonym

Prawo 333, 2021

(C) for this edition by CNS 
W przypadku braku obowiązującego miejscowego planu zagospodarowania przestrzennego na danym obszarze, określenie sposobów zagospodarowania i warunków zabudowy terenu zasadniczo ${ }^{16}$ następuje w formie decyzji ustalającej warunki zabudowy i zagospodarowania terenu. Przy tym lokalizację inwestycji celu publicznego ustala się w decyzji o lokalizacji inwestycji celu publicznego ${ }^{17}$, a sposób zagospodarowania terenu i warunki zabudowy dla innych inwestycji ustala się $\mathrm{w}$ decyzji o warunkach zabudowy ${ }^{18}$. Przedmiotowa decyzja powinna zawierać w szczególności elementy wskazane w art. 54 u.p.z.p. czyli określać rodzaj inwestycji, warunki i szczegółowe zasady zagospodarowania terenu oraz jego zabudowy wynikające z przepisów odrębnych, a także linie rozgraniczające teren inwestycji ${ }^{19}$. Rozstrzygnięcie to stanowi zatem wytyczne w zakresie możliwości inwestycyjnych określonego w nim terenu, co powoduje, że decyzje ustalające warunki zabudowy i zagospodarowania terenu są postrzegane — choć w ograniczonym zakresie - jako surogat miejscowego planu zagospodarowania przestrzennego ${ }^{20}$. Przedmiotowe decyzje lokalizacyjne są wiążące dla organów wydających rozstrzygnięcie $\mathrm{w}$ przedmiocie pozwolenia na budowę ${ }^{21}$, w związku

terminie. Po bezskutecznym upływie tego terminu wojewoda sporządza miejscowy plan zagospodarowania przestrzennego albo jego zmianę dla obszaru, którego dotyczy zaniechanie gminy, w zakresie koniecznym dla możliwości realizacji inwestycji celu publicznego oraz wydaje w tej sprawie zarządzenie zastępcze, przy czym przyjęty w tym trybie plan wywołuje skutki prawne takie jak miejscowy plan zagospodarowania przestrzennego (szerzej na ten temat zob. K. Małysa-Sulińska, Rozstrzygnięcia ograniczajace samodzielność planistyczna gminy w toku sporządzania miejscowego planu zagospodarowania przestrzennego, [w:] Nadzór nad samorządem a granice jego samodzielności, red. M. Stec, M. Mączyński, Warszawa 2011, s. 157-159.

16 Zob. jednak art. 50 ust. 2 oraz art. 59 ust. 1 i 2 u.p.z.p., w którym wskazano wyjątki od obowiązku uzyskania decyzji lokalizacyjnej w przypadku planowania — objętej regulacjami ogólnymi z tego zakresu - realizacji inwestycji na terenie niepodlegającym ustaleniom obowiązującego miejscowego planu zagospodarowania przestrzennego (na ten temat zob. Planowanie..., s. 392 n. oraz s. 481 n.; A. Despot-Mładanowicz, [w:] Ustawa o planowaniu i zagospodarowaniu przestrzennym. Komentarz, red. M. Wierzbowski, A. Plucińska-Filipowicz, Warszawa 2016, s. 547 n. oraz 603 n.).

17 Zob. art. 4 ust. 2 pkt 1 u.p.z.p. (na temat tej decyzji zob. M. Szewczyk, op. cit., s. 365 n.; K. Małysa-Sulińska, Administracyjnoprawne aspekty inwestycji budowlanych, Warszawa 2012, s. 46 n. Zob. także M. Szewczyk, Lokalizacja inwestycji publicznych w świetle nowej ustawy o planowaniu i zagospodarowaniu przestrzennym, „Casus” 2003, nr 28, s. 6 n.; K. Małysa-Sulińska, Zakres przedmiotowy przedsięwzięć, dla których warunki zabudowy i zagospodarowania terenu określane sa w formie decyzji o ustaleniu lokalizacji inwestycji celu publicznego, „Casus” 2009, nr 53, s. 6 n.).

18 Zob. art. 4 ust. 2 pkt 2 u.p.z.p. (na temat tej decyzji zob. M. Szewczyk, op. cit., s. 365 n.; K. Małysa-Sulińska, Administracyjnoprawne aspekty..., s. 95 n.).

19 Szerzej na temat treści decyzji ustalającej warunki zabudowy i zagospodarowania terenu zob. K. Małysa-Sulińska, Administracyjnoprawne aspekty inwestycji budowlanych, Warszawa 2012, s. 75 n.

20 Szerzej na ten temat zob. M. Szewczyk, op. cit., s. 209 n.

21 Zob. art. 55 u.p.z.p., w którym wskazano, że decyzja o ustaleniu lokalizacji inwestycji celu publicznego wiąże organ wydający decyzję o pozwoleniu na budowę, a przepis ten — zgodnie z regulacją art. 64 ust. 1 u.p.z.p. - stosuje się odpowiednio do decyzji o warunkach zabudowy. 
z czym wydanie tej decyzji stanowi dla jej adresata prawnie wiążące i skuteczne erga omnes potwierdzenie możliwości zagospodarowania terenu w sposób w niej ustalony $^{22}$. Mając na uwadze powyższe, należy zaznaczyć, iż wskazane powyżej decyzje lokalizacyjne — co do zasady — wydawane są przez organ wykonawczy w gminie, czyli wójta, burmistrza albo prezydenta miasta. Zauważyć trzeba jednak, że ustawodawca wprowadził wyjątki w tym zakresie, stanowiąc, iż decyzje te na terenach zamkniętych wydawane są przez organ administracji rządowej, czyli wojewodę ${ }^{23}$, a w przypadku lokalizacji inwestycji celu publicznego o znaczeniu krajowym i wojewódzkim — wójta (burmistrza albo prezydenta miasta) działającego w uzgodnieniu z marszałkiem województwa ${ }^{24}$.

Z powyższego wynika, że — jak wskazano w u.p.z.p. — kształtowanie i prowadzenie polityki przestrzennej na terenie gminy, w tym między innymi uchwalanie miejscowych planów zagospodarowania przestrzennego, ustawodawca zasadniczo powierzył gminie ${ }^{25}$. Jednocześnie w przepisach u.p.z.p. zastrzeżono, iż decydowanie o przeznaczeniu danego obszaru, rozmieszczeniu inwestycji celu publicznego oraz sposobie zagospodarowania i warunkach zabudowy terenu nie stanowi — jak to podano powyżej — wyłącznej kompetencji organów gminy ${ }^{26}$. Wskazać należy również, że samodzielność organów gminy w przedmiotowym zakresie podlega ograniczeniom wynikającym z konieczności współdziałania $\mathrm{z}$ innymi organami, chociażby w zakresie uzgodnienia projektu miejscowego planu zagospodarowania przestrzennego ${ }^{27}$ czy projektu decyzji ustalającej warunki zabudowy i zagospodarowania terenu ${ }^{28}$.

22 Zob. M. Szewczyk, op. cit., s. 209-210.

23 Zob. art. 51 ust. 1 pkt 3 i art. 60 ust. 3 u.p.z.p.

24 Zob. art. 51 ust. 1 pkt 1 u.p.z.p.

25 Zob. art. 3 ust. 1 u.p.z.p. W doktrynie przedmiotu podnosi się jednak, że niezbyt fortunne było zaliczenie przez ustawodawcę miejscowego planu zagospodarowania przestrzennego do działań opisanych jako prowadzenie polityki przestrzennej (zob. Planowanie..., s. 34). Plan miejscowy ma bowiem całkowicie odmienny charakter prawny niż - wymienione również w art. 3 ust. 1 u.p.z.p. - studium uwarunkowań i kierunków zagospodarowania przestrzennego gminy (szerzej na ten temat zob. K. Małysa-Sulińska, Ramowe studium..., s. 94-95; eadem, Normy ksztattujace ład przestrzenny, Warszawa 2008, s. 72 n.).

26 Zob. również art. 4 ust. 1a u.p.z.p., zgodnie z którym w odniesieniu do obszarów morskich wód wewnętrznych, morza terytorialnego i wyłącznej strefy ekonomicznej przeznaczenie terenu, rozmieszczenie inwestycji celu publicznego oraz sposób zagospodarowania i warunki zabudowy terenu określa się na podstawie przepisów ustawy z dnia 21 marca 1991 roku o obszarach morskich Rzeczypospolitej Polskiej i administracji morskiej, Dz.U. z 2020 r. poz. 2135 ze zm. Nadto zob. art. 4 ust. 3 u.p.z.p., w którym wskazano, że w odniesieniu do terenów zamkniętych w miejscowym planie zagospodarowania przestrzennego ustala się tylko granice tych terenów oraz granice ich stref ochronnych, a w strefach ochronnych ustala się ograniczenia w zagospodarowaniu i korzystaniu z terenów, w tym zakaz zabudowy, przy czym — zgodnie z ust. 4 przywołanego artykuł — przepisów tych nie stosuje się do terenów zamkniętych ustalanych przez ministra właściwego do spraw transportu.

27 Zob. art. 17 pkt 6 lit. b) u.p.z.p.

28 Zob. art. 53 ust. 4 w zw. $z$ art. 64 ust. 1 u.p.z.p. 
Nadto podkreślenia wymaga, że przywołane powyżej regulacje u.p.z.p. nie znajdują zastosowania w odniesieniu do wszystkich rodzajów zamierzeń budowlanych. Dla szerokiej grupy inwestycji, których realizację uznano za istotną oraz pożądaną dla prawidłowego rozwoju naszego kraju, wprowadzono bowiem inne zasady ich lokalizacji przy jednoczesnym przeniesieniu kompetencji w tym zakresie z organów gminy na organy administracji rządowej. Stosowne regulacje we wspomnianej kwestii zostały ujęte $\mathrm{w}$ następujących specustawach inwestycyjnych: specustawie kolejowej ${ }^{29}$, specustawie drogowej ${ }^{30}$, specustawie EURO $2012^{31}$, specustawie lotniskowej ${ }^{32}$, specustawie terminalowej ${ }^{33}$, specustawie telekomunikacyjnej ${ }^{34}$, specustawie przeciwpowodziowej ${ }^{35}$, specustawie atomowej ${ }^{36}$, specustawie przesyłowej ${ }^{37}$, specustawie przekopowej ${ }^{38}$, specustawie o $\mathrm{CPK}^{39}$, specustawie naftowej ${ }^{40}$, specustawie Westerplatte ${ }^{41}$, specustawie portowej ${ }^{42}$. Zgodnie z przepisami przywołanych ustaw ${ }^{43}$, lokalizacja przedsięwzięcia zasad-

29 Ustawa z dnia 28 marca 2003 roku o transporcie kolejowym, Dz.U. z 2019 r. poz. 710 ze zm.

30 Ustawa z dnia 10 kwietnia 2003 roku o szczególnych zasadach przygotowania i realizacji inwestycji w zakresie dróg publicznych, Dz.U. z 2018 r. poz. 1474 ze zm.

31 Ustawa z dnia 7 września 2007 roku o przygotowaniu finałowego turnieju Mistrzostw Europy w Piłce Nożnej UEFA EURO 2012, Dz.U. z 2017 r. poz. 1372 ze zm.

32 Ustawa z dnia 12 lutego 2009 roku o szczególnych zasadach przygotowywania i realizacji inwestycji w zakresie lotnisk użytku publicznego, Dz.U. z 2018 r. poz. 1380.

33 Ustawa z dnia 24 kwietnia 2009 roku o inwestycjach w zakresie terminalu regazyfikacyjnego skroplonego gazu ziemnego w Świnoujściu, Dz.U. z 2019 r. poz. 1554 ze zm.

34 Ustawa z dnia 7 maja 2010 roku o wspieraniu rozwoju usług i sieci telekomunikacyjnych, Dz.U. z 2019 r. poz. 2410 ze zm.

35 Ustawa z dnia 8 lipca 2010 roku o szczególnych zasadach przygotowania inwestycji w zakresie budowli przeciwpowodziowych, Dz.U. z 2019 r. poz. 933.

36 Ustawa z dnia 29 czerwca 2011 roku o przygotowaniu i realizacji inwestycji w zakresie obiektów energetyki jądrowej oraz inwestycji towarzyszących, Dz.U. z 2018 r. poz. 1537.

37 Ustawa z dnia 5 sierpnia 2015 roku o przygotowaniu i realizacji strategicznych inwestycji w zakresie sieci przesyłowych, Dz.U. z 2020 r. poz. 191 ze zm.

38 Ustawa z dnia 24 lutego 2017 roku o inwestycjach w zakresie budowy drogi wodnej łączącej Zalew Wiślany z Zatoką Gdańską, Dz.U. z 2019 r. poz. 1073.

39 Ustawa z dnia 10 maja 2018 roku o Centralnym Porcie Komunikacyjnym, Dz.U. z 2020 r. poz. 234.

40 Ustawa z dnia 22 lutego 2019 roku o przygotowaniu i realizacji strategicznych inwestycji w sektorze naftowym, Dz.U. z 2020 r. poz. 2309 ze zm.

41 Ustawa z dnia 19 lipca 2019 roku o inwestycjach w zakresie budowy Muzeum Westerplatte i Wojny 1939 - Oddziału Muzeum II Wojny Światowej w Gdańsku, Dz.U. poz. 1589 .

42 Ustawa z dnia 9 sierpnia 2019 roku o inwestycjach w zakresie budowy portów zewnętrznych, Dz.U. poz. 1924 ze zm.

43 Do specustaw inwestycyjnych zaliczane są również: ustawa z dnia 11 sierpnia 2001 roku o szczególnych zasadach odbudowy, remontów i rozbiórek obiektów budowlanych zniszczonych lub uszkodzonych w wyniku działania żywiołu, Dz.U. z 2020 r. poz. 764 (tak zwana specustawa żywiołowa), ustawa o inwestycjach w zakresie budowy lub przebudowy toru wodnego Świnoujście - Szczecin (tak zwana specustawa Świnoujście - Szczecin), ustawa z dnia 20 maja 2016 roku o inwestycjach w zakresie elektrowni wiatrowych, Dz.U. z 2019 r. poz. 654 ze zm. (tak zwana specustawa wiatrowa), ustawa o ułatwieniach w przygotowaniu i realizacji inwestycji mieszkaniowych 
niczo następuje w oderwaniu od ustaleń przyjętych w obowiązującym miejscowym planie zagospodarowania przestrzennego, a organem właściwym do jej ustalenia jest wojewoda ${ }^{44}$. Mając zaś na uwadze zauważalną tendencję ustawodawcy do obejmowania coraz szerszej kategorii zamierzeń budowlanych regulacjami specustaw inwestycyjnych, trzeba wskazać, że kompetencje gminy w zakresie określania sposobów zagospodarowania i warunków zabudowy dla terenów położonych na ich obszarze podlegają stopniowemu ograniczaniu ${ }^{45}$.

Podnieść zatem trzeba, iż władztwo planistyczne gminy w przypadku konieczności uzyskania decyzji lokalizacyjnej ograniczone jest do przypadków, gdy decyzja ta wydawana jest na podstawie przepisów ogólnych ujętych w u.p.z.p. W związku z powyższym poniżej analizie poddano przepisy determinujące ustalenie warunków zabudowy i zagospodarowania terenu w tej formie.

\section{Przesłanki wydawanych na zasadach ogólnych decyzji ustalających warunki zabudowy i zagospodarowania terenu}

Jeśli na danym terenie nie obowiązuje miejscowy plan zagospodarowania przestrzennego, to - co wskazano już powyżej — ustalenie sposobów zagospodarowania i warunków zabudowy terenu następuje w formie decyzji o warunkach zabudowy i zagospodarowania terenu, która może przybrać postać albo decyzji o lokalizacji inwestycji celu publicznego, albo decyzji o warunkach zabudowy. Ustawodawca przyjął zatem rozwiązanie, zgodnie z którym ewentualna kwalifikacja przedsięwzięcia jako inwestycji celu publicznego ${ }^{46}$ determinuje tryb ju-

oraz inwestycji towarzyszących (tak zwana specustawa mieszkaniowa), przy czym przepisami tych ustaw zasadniczo nie pozbawiono organów gminy kompetencji w zakresie kształtowania ładu przestrzennego, choć zmodyfikowano ogólne rozwiązania prawne obowiązujące w tym zakresie (na ten temat zob. np. K. Małysa-Sulińska, Mnogość trybów ustalania lokalizacji inwestycji mieszkaniowej i inwestycji jej towarzyszącej jako konsekwencja wejścia w życie przepisów specustawy mieszkaniowej, [w:] Specustawy inwestycyjno-budowlane, red. T. Bąkowski, Gdańsk 2020, s. 219 n.).

44 Szerzej na ten temat zob. K. Małysa-Sulińska, Postępowania w sprawach inwestycyjno-budowlanych prowadzone $w$ oparciu o regulacje szczególne ujęte w przepisach specustaw inwestycyjnych, [w:] System administracyjnego prawa procesowego, red. A. Matan, G. Łaszczyca, t. 4. Postepowania autonomiczne i szczególne. Postępowania niejurysdykcyjne, red. tomu A. Matan, Warszawa 2021, s. 453 n.

45 Szerzej na temat skali tego procesu zob. T. Bąkowski, O skali normatywnej $i$ wadze teoretycznej specustaw inwestycyjno-budowlanych oraz o motywach ich stanowienia, [w:] Specustawy inwestycyjno-budowlane, red. T. Bąkowski, Gdańsk 2020, s. 67 n.

46 Zgodnie z regulacją art. 2 pkt 5 u.p.z.p. pod pojęciem inwestycji celu publicznego należy rozumieć działania o znaczeniu lokalnym (gminnym) i ponadlokalnym (powiatowym, wojewódzkim i krajowym), a także krajowym (obejmującym również inwestycje międzynarodowe i ponadregio- 
rysdykcyjny, w jakim może być procedowane postępowanie w sprawie ustalenia warunków zabudowy i zagospodarowania terenu. Tryby te różnią się między sobą, przy czym w każdym z nich ustalenie warunków zabudowy i zagospodarowania terenu uzależnione jest od spełnienia przesłanek wydania pozytywnej decyzji w sprawie. Przedmiotowe decyzje lokalizacyjne — zarówno o lokalizacji inwestycji celu publicznego, jak i o warunkach zabudowy — są bowiem rozstrzygnięciami związanymi. Oznacza to, że organ właściwy w sprawie lokalizacji inwestycji bada stan faktyczny pod kątem wymagań określonych w przepisach prawa. Jeśli w toku tych ustaleń organ stwierdzi niezgodność lokalizacji inwestycji z tymi wymaganiami to jest zobligowany do wydania decyzji odmownej, a jeśli jej nie stwierdzi — musi wydać decyzję ustalającą warunki zabudowy i zagospodarowania terenu.

Przesłanki wydania decyzji ustalającej warunki zabudowy i zagospodarowania terenu zostały określone odrębnie w odniesieniu do poszczególnych rodzajów decyzji lokalizacyjnych. I tak wydanie decyzji o warunkach zabudowy - co do zasady $^{47}$ — jest możliwe w przypadku łącznego spełnienia następujących przesłanek: co najmniej jedna działka sąsiednia, dostępna z tej samej drogi publicznej, jest zabudowana w sposób pozwalający na określenie wymagań dotyczących nowej zabudowy w zakresie kontynuacji funkcji, parametrów, cech i wskaźników kształtowania zabudowy oraz zagospodarowania terenu, w tym gabarytów i formy architektonicznej obiektów budowlanych, linii zabudowy oraz intensywności wykorzystania terenu ${ }^{48}$; teren ma dostęp do drogi publicznej ${ }^{49}$; istniejące lub projektowane uzbrojenie terenu jest wystarczające dla zamierzenia budowlanego ${ }^{50}$; teren nie wymaga uzyskania zgody na zmianę przeznaczenia gruntów rolnych

nalne), oraz metropolitalnym (obejmującym obszar metropolitalny) bez względu na status podmiotu podejmującego te działania oraz źródła ich finansowania, stanowiące realizację celów, o których mowa w art. 6 ustawy z dnia 21 sierpnia 1997 roku o gospodarce nieruchomościami, Dz.U. z 2020 r. poz. 1990 ze zm. Szerzej na temat przesłanek kwalifikowania przedsięwzięcia jako inwestycji celu publicznego zob. K. Małysa-Sulińska, Zakres przedmiotowy przedsięwzięć, dla których warunki zabudowy i zagospodarowania terenu określane sq w formie decyzji o ustaleniu lokalizacji inwestycji celu publicznego, „Casus” 2009, nr 53, s. 6 n.

${ }^{47}$ Ustawodawca przewidział jednak wyjątki od tej zasady. Zob. art. 61 ust. 2 u.p.z.p., w którym wskazano, że przepisów art. 61 ust. 1 pkt 1 tej ustawy nie stosuje się do inwestycji produkcyjnych lokalizowanych na terenach przeznaczonych na ten cel w planach miejscowych, które utraciły moc na podstawie art. 67 ust. 1 u.z.p. Zob. również art. 61 ust. 3 u.p.z.p., zgodnie z którym przepisów art. 61 ust. 1 pkt 1 i 2 tej ustawy nie stosuje się do linii kolejowych, obiektów liniowych i urządzeń infrastruktury technicznej, a także instalacji odnawialnego źródła energii w rozumieniu art. 2 pkt 13 ustawy z dnia 20 lutego 2015 roku o odnawialnych źródłach energii (Dz.U. 2018 poz. 2389 ze zm.). Nadto zob. art. 61 ust. 4 u.p.z.p. stanowiącym, iż przepisów art. 61 ust. 1 pkt 1 tej ustawy nie stosuje się do zabudowy zagrodowej, w przypadku, gdy powierzchnia gospodarstwa rolnego związanego z tą zabudową przekracza średnią powierzchnię gospodarstwa rolnego w danej gminie.

48 Zob. art. 61 ust. 1 pkt 1 u.p.z.p.

49 Zob. art. 61 ust. 1 pkt 2 u.p.z.p.

50 Zob. art. 61 ust. 1 pkt 3 u.p.z.p. 
i leśnych na cele nierolnicze i nieleśne albo jest objęty zgodą uzyskaną przy sporządzaniu miejscowych planów, które utraciły moc na podstawie ustawy z dnia 7 lipca 1994 roku o zagospodarowaniu przestrzennym (Dz.U. z 1999 r. Nr 15, poz. 139 ze zm.; dalej: u.z.p. $)^{51}$; decyzja jest zgodna z przepisami odrębnymi ${ }^{52}$, zamierzenie budowlane nie znajduje się w obszarze: a) w stosunku do którego decyzją o ustaleniu lokalizacji strategicznej inwestycji w zakresie sieci przesyłowej, o której mowa w art. 5 ust. 1 ustawy z dnia 24 lipca 2015 roku o przygotowaniu i realizacji strategicznych inwestycji w zakresie sieci przesyłowych, ustanowiony został zakaz, o którym mowa w art. 22 ust. 2 pkt 1 tej ustawy, b) strefy kontrolowanej wyznaczonej po obu stronach gazociągu, c) strefy bezpieczeństwa wyznaczonej po obu stronach rurociągu ${ }^{53}$. Natomiast wydanie decyzji o ustaleniu lokalizacji inwestycji celu publicznego zasadniczo ${ }^{54}$ determinowane jest spełnieniem wyłącznie dwóch przywołanych powyżej przesłanek ${ }^{55}$.

Analizując te przesłanki - a rozpoczynając od tych, których spełnienie determinuje wydanie obu omawianych rodzajów decyzji lokalizacyjnych — wskazać należy, że przedmiotowe decyzje mogą być wydane wyłącznie wówczas, gdy $\mathrm{w}$ toku postępowania potwierdzone zostanie, że lokalizację planowanego zamierzenia inwestycyjnego można pogodzić z przepisami prawa powszechnie obowiązującego. Zauważyć przy tym należy, że wymóg ten obejmuje nie tylko przepisy ujęte w u.p.z.p., ale także w innych aktach normatywnych o mocy powszechnie obowiązującej. Jednocześnie podkreślić należy, że wyjątek w tym zakresie stanowi regulacja art. 1 ust. 2 u.p.z.p. ${ }^{56}$, a w związku z tym wartości uwzględnianie w planowaniu i zagospodarowania przestrzennego nie mogą stanowić wyłącznej odmowy ustalenia w formie decyzji warunków zabudowy i zagospodarowania terenu. Oznacza to, że odmowa wydania decyzji lokalizacyjnej, o której mowa w przepisach u.p.z.p., może opierać się na wyraźnej sprzeczności planowanego zamierzenia z przepisem nakładającym expressis verbis konkretne ograniczenia ${ }^{57}$.

Kolejną przesłanką, która zasadniczo ma zastosowanie w obydwu rodzajach postępowań lokalizacyjnych prowadzonych w oparciu o przepisy u.p.z.p., jest

51 Zob. art. 61 ust. 1 pkt 4 u.p.z.p.

52 Zob. art. 61 ust. 1 pkt 5 u.p.z.p.

53 Zob. art. 61 ust. 1 pkt 6 u.p.z.p.

54 Wyjątek od zasady ujęto w art. 50 ust. 1a u.p.z.p., zgodnie z którym przepisu art. 61 ust. 1 pkt 4 przedmiotowej ustawy nie stosuje się do inwestycji celu publicznego w przypadkach uzasadnionych potrzebami obronności lub bezpieczeństwa państwa albo ochrony granicy państwowej, a także do inwestycji celu publicznego z zakresu łączności publicznej.

55 Zob. art. art. 50 ust. $1 \mathrm{a}$ oraz art. 56 zd. 1 u.p.z.p.

56 Zob. art. 56 zd. 2 u.p.z.p., zgodnie z którym przepis art. 1 ust. 2 przywołanej ustawy nie może stanowić wyłącznej podstawy odmowy ustalenia lokalizacji inwestycji celu publicznego, przy czym — zgodnie z art. 64 ust. 1 u.p.z.p. — przepis ten stosuje się odpowiednio do decyzji o warunkach zabudowy.

57 Szerzej na temat regulacji ujętej w art. 56 u.p.z.p. zob. K. Małysa-Sulińska, Administracyjnoprawne..., s. $66 \mathrm{n}$. 
brak wymogu uzyskania zgody na zmianę przeznaczenia gruntów rolnych i leśnych na cele nierolnicze i nieleśne w odniesieniu do terenu inwestycji albo objęcie tego terenu zgodą uzyskaną przy sporządzaniu miejscowych planów, które - na podstawie ustawy z dnia 7 lipca 1994 roku o zagospodarowaniu przestrzennym utraciły moc. Przesłanka ta zachodzi albo gdy grunty stanowiące teren planowanej inwestycji nie są kwalifikowane jako rolne ${ }^{58}$ lub leśne ${ }^{59}$, albo gdy stanowią użytki rolne położone $\mathrm{w}$ granicach administracyjnych miast ${ }^{60}$, albo - będąc położonymi poza granicami administracyjnymi miast - stanowią grunty rolne klasy IV, IVa, IVb, V, VI, VIz lub o nieoznaczonej klasie ${ }^{61}$. Nadto dopuszczalne jest wydanie decyzji o warunkach zabudowy i zagospodarowania terenu dla gruntów rolnych klasy I, II, III, IIIa i IIIb, które znajdują się poza granicami administracyjnymi miast, ale tylko wówczas, gdy spełnione są łącznie wszystkie przesłanki wskazane w art. 7 ust. 2 a u.o.g.r.1. ${ }^{62}$. Ustalenie warunków zabudowy i zagospodarowania

58 Gruntami rolnymi - zgodnie z art. 2 ust. 1 ustawy z dnia 3 lutego 1995 roku o ochronie gruntów rolnych i leśnych, Dz.U. z 2017 r. poz. 1161 ze zm. (dalej: u.o.g.r.l.) — są grunty: (pkt 1) określone w ewidencji gruntów jako użytki rolne; (pkt 2) pod stawami rybnymi i innymi zbiornikami wodnymi, służącymi wyłącznie dla potrzeb rolnictwa; (pkt 3) pod wchodzącymi w skład gospodarstw rolnych budynkami mieszkalnymi oraz innymi budynkami i urządzeniami służącymi wyłącznie produkcji rolniczej oraz przetwórstwu rolno-spożywczemu; (pkt 4) pod budynkami i urządzeniami służącymi bezpośrednio do produkcji rolniczej uznanej za dział specjalny, stosownie do przepisów o podatku dochodowym od osób fizycznych i podatku dochodowym od osób prawnych; (pkt 5) parków wiejskich oraz pod zadrzewieniami i zakrzewieniami śródpolnymi, w tym również pod pasami przeciwwietrznymi i urządzeniami przeciwerozyjnymi; (pkt 6) rodzinnych ogrodów działkowych i ogrodów botanicznych; (pkt 7) pod urządzeniami: melioracji wodnych, przeciwpowodziowych i przeciwpożarowych, zaopatrzenia rolnictwa w wodę, kanalizacji oraz utylizacji ścieków i odpadów dla potrzeb rolnictwa i mieszkańców wsi; (pkt 8) zrekultywowane dla potrzeb rolnictwa; (pkt 9) torfowisk i oczek wodnych; (pkt 10) pod drogami dojazdowymi do gruntów rolnych. Natomiast - jak wskazano w art. 2 ust. 3 u.o.g.r.l. — nie uważa się za grunty rolne gruntów znajdujących się pod parkami i ogrodami wpisanymi do rejestru zabytków.

59 Gruntami leśnymi — zgodnie z art. 2 ust. 2 u.o.g.r.l. — są grunty: (pkt 1) określone jako lasy w przepisach o lasach; (pkt 2) zrekultywowane dla potrzeb gospodarki leśnej; (pkt 3) pod drogami dojazdowymi do gruntów leśnych.

60 Zob. art. 10a u.o.g.r.l., w którym wskazano, że przepisów rozdziału 2, zatytułowanego Ograniczanie przeznaczania gruntów na cele nierolnicze i nieleśne, nie stosuje się do gruntów rolnych położonych w granicach administracyjnych miast.

61 Zob. art. 7 ust. 1 u.o.g.r.l., w którym wskazano, że przeznaczenia gruntów rolnych i leśnych na cele nierolnicze i nieleśne, wymagającego zgody, o której mowa w ust. 2, dokonuje się w miejscowym planie zagospodarowania przestrzennego, sporządzonym w trybie określonym w przepisach o planowaniu i zagospodarowaniu przestrzennym, przy czym w przywołanym ust. 2 spośród gruntów rolnych wskazano wyłącznie użytki rolne klas I-III.

${ }^{62}$ Zob. art. 7 ust. 2a u.o.g.r.l., w którym wskazano, że nie wymaga uzyskania zgody ministra właściwego do spraw rozwoju wsi przeznaczenie na cele nierolnicze i nieleśne gruntów rolnych stanowiących użytki rolne klas I-III, jeżeli grunty te spełniają łącznie następujące warunki: (pkt 1) co najmniej połowa powierzchni każdej zwartej części gruntu zawiera się w obszarze zwartej zabudowy; (pkt 2) położone są w odległości nie większej niż $50 \mathrm{~m}$ od granicy najbliższej działki budowlanej w rozumieniu przepisów ustawy z dnia 21 sierpnia 1997 roku o gospodarce nieruchomościami, Dz.U. z 2020 r. poz. 1990 ze zm. (w dalszej części przywoływana jako u.g.n.); (pkt 3) położone są w odległo-

Prawo 333, 2021

(C) for this edition by CNS 
terenu dla gruntu sklasyfikowanego jako rolny lub leśnych może nastąpić również wtedy, gdy w odniesieniu do tego terenu zgoda na zmianę przeznaczenia na cele nierolnicze i nieleśne została udzielona przy sporządzaniu miejscowego planu zagospodarowania przestrzennego, który obowiązywał w dniu 1 stycznia 1995 roku, a utracił moc na podstawie art. 67 u.z.p., z zastrzeżeniem jednak, że zgoda ta miała skutek w postaci wprowadzenia adekwatnych ustaleń w planie miejscowym ${ }^{63}$.

Następną przesłanką, która — podobnie jak pozostałe przedstawione poniżej — może podlegać weryfikacji wyłącznie w toku postępowania zmierzającego do wydania decyzji o warunkach zabudowy, jest dostęp terenu planowanej inwestycji do drogi publicznej ${ }^{64}$. Przesłanka ta zostaje spełniona nie tylko wówczas, gdy teren planowanej inwestycji ma bezpośredni dostęp do drogi publicznej, ale także gdy dostęp ten jest przez drogę wewnętrzną lub ustanowioną służebność drogową ${ }^{65}$. Mając na uwadze powyższe, należy zauważyć, że do kategorii dróg publicznych zalicza się drogi krajowe, wojewódzkie, powiatowe oraz gminne ${ }^{66}$. Podkreślenia wymaga przy tym, że dostęp do drogi publicznej musi być legalny, a w związku z tym prawo do korzystania z niego powinno wynikać wprost z przepisu prawa, czynności prawnej, orzeczenia sądowego czy też administracyjnego ${ }^{67}$.

Kolejna przesłanka, która zasadniczo podlega weryfikacji w toku postępowania o ustalenie warunków zabudowy, sprowadza się do weryfikacji, czy istniejące lub projektowane uzbrojenie terenu jest wystarczające dla planowanej inwestycji budowlanej, przy czym pod pojęciem uzbrojenia terenu należy rozumieć drogi, obiekty budowlane, urządzenia i przewody, o których mowa w art. 143 ust. 2 u.g.n., czyli również - wybudowane pod ziemią, na ziemi albo nad ziemią — przewody lub urządzenia wodociągowe, kanalizacyjne, ciepłownicze, elektryczne, gazowe i telekomunikacyjne ${ }^{68}$. Mając na uwadze powyższe, trzeba

ści nie większej niż 50 metrów od drogi publicznej w rozumieniu przepisów ustawy z dnia 21 marca 1985 roku o drogach publicznych ustawy z dnia 21 marca 1985 roku o drogach publicznych, Dz.U. z 2020 r. poz. 470 ze zm. (w dalszej części powoływana jako u.d.p.); (pkt 4) ich powierzchnia nie przekracza 0,5 ha, bez względu na to, czy stanowią jedną całość, czy stanowią kilka odrębnych części.

${ }^{63}$ Szerzej na temat wskazanej w art. 61 ust. 1 pkt 4 u.p.z.p. przesłanki wydania decyzji lokalizacyjnej zob. K. Małysa-Sulińska, Administracyjnoprawne..., s. 64 n.

64 Zgodnie z regulacją art. 1 u.d.p., drogą publiczną jest droga zaliczona na podstawie przedmiotowej ustawy do jednej z kategorii dróg, z której może korzystać każdy, zgodnie z jej przeznaczeniem, z ograniczeniami i wyjątkami określonymi w tej ustawie lub innych przepisach szczególnych.

65 Zob. art. 2 pkt 14 u.p.z.p.

66 Zob. art. 2 ust. 1 u.d.p. Zaliczenie drogi do jednej ze wskazanych powyżej kategorii następuje odpowiednio w: rozporządzeniu ministra właściwego do spraw transportu (art. 5 ust. 2 u.d.p.), uchwale sejmiku województwa (art. 6 ust. 2 u.d.p.), uchwale rady powiatu (art. 6a ust. 2 u.d.p.) lub uchwale rady gminy (art. 7 ust. 2 u.d.p.). Szerzej na temat dróg publicznych zob. L. Bielecki, Drogi publiczne, [w:] Prawo administracyjne - część szczególowa, red. P. Ruczkowski, t. 2, Warszawa 2011, s. $41 \mathrm{n}$.

67 Szerzej na temat wskazanej w art. 61 ust. 1 pkt 2 u.p.z.p. przesłanki wydania decyzji o warunkach zabudowy zob. K. Małysa-Sulińska, Administracyjnoprawne..., s. 106 n.

68 Zob. art. 2 pkt 13 u.p.z.p. 
podkreślić, że wydanie wskazanej decyzji lokalizacyjnej jest możliwe zarówno wówczas, gdy teren planowanej inwestycji jest uzbrojony w stopniu adekwatnym do jej potrzeb, jak i wtedy, gdy wykonanie przedmiotowego uzbrojenia zostanie zagwarantowane $\mathrm{w}$ drodze umowy zawartej między właściwą jednostką organizacyjną a inwestorem ${ }^{69}$. Ustalenia organu w zakresie weryfikacji tej przesłanki wymagają natomiast dokonania $\mathrm{w}$ toku postępowania lokalizacyjnego — bazującej na parametrach planowanego zamierzenia budowlanego - oceny zapotrzebowania na media ${ }^{70}$ dla inwestycji objętej wnioskiem ${ }^{71}$.

Nowym jest rozwiązanie, zgodnie z którym możliwość wydania decyzji o warunkach zabudowy podlega ograniczeniom wynikającym z - jak ujęli to projektodawcy tych rozwiązań - konieczności dalszego usprawniania inwestycji sieciowych, które stopniem rozwoju nie odpowiadają wyzwaniom związanym $\mathrm{z}$ transformacją energetyczną Rzeczypospolitej Polskiej ${ }^{72}$. Od 27 maja 2021 ro$\mathrm{ku}^{73}$ obowiązuje bowiem art. 61 ust. 1 pkt 6 u.p.z.p., zgodnie z którym niedopuszczalne jest wydanie omawianej decyzji lokalizacyjnej, jeśli w pozostającej w obrocie prawnym decyzji o ustaleniu lokalizacji strategicznej inwestycji w zakresie sieci przesyłowej dla obszaru inwestycji objętej wnioskiem o warunki zabudowy ustanowiono zakaz wznoszenia i utrzymywania obiektów budowlanych przeznaczonych na pobyt ludzi. Ustawodawca wykluczył również możliwość wydania decyzji o warunkach zabudowy dla obszaru znajdującego się w strefie kontrolowanej gazociągu, czyli w obszarze wyznaczonym po obu stronach osi gazociągu, którego linia środkowa pokrywa się z osią gazociągu. W obszarze tym przedsiębiorstwo energetyczne zajmujące się transportem gazu ziemnego podejmuje czynności w celu zapobieżenia działalności mogącej mieć negatywny wpływ na trwałość i prawidłowe użytkowanie gazociągu ${ }^{74}$. Tożsame rozwiązanie przyjęto także w odniesieniu do strefy bezpieczeństwa rurociągu, która jest wyznaczana dla rurociągów przesyłowych dalekosiężnych ${ }^{75}$.

69 Zob. art. 61 ust. 5 u.p.z.p.

70 Zob. wyrok WSA w Poznaniu z dnia 6 października 2009 roku, sygn. II SA/Po 744/08, LEX nr 573831.

71 Szerzej na temat wskazanej w art. 61 ust. 1 pkt 3 u.p.z.p. przesłanki wydania decyzji o warunkach zabudowy zob. K. Małysa-Sulińska, Administracyjnoprawne..., s. 108 n.

72 Zob. uzasadnienie do ustawy z dnia 20 kwietnia 2021 roku o zmianie ustaw regulujących przygotowanie i realizację kluczowych inwestycji w zakresie strategicznej infrastruktury energetycznej (dalej: u.z.i.e.)

73 Zauważenia wymaga jednak, że — zgodnie z art. 9 ust. 1 u.z.i.e. — do postępowań w sprawie wydania decyzji lokalizacyjnych wszczętych i niezakończonych przed dniem wejścia w życie niniejszej ustawy decyzją ostateczną, stosuje się przepisy u.p.z.p. brzmieniu dotychczasowym.

74 Zob. § 2 pkt 30 rozporządzenia Ministra Gospodarki z dnia 26 kwietnia 2013 roku w sprawie warunków technicznych, jakim powinny odpowiadać sieci gazowe i ich usytuowanie.

75 Zob. § 136 rozporządzenia Ministra Gospodarki z dnia 21 listopada 2005 roku w sprawie warunków technicznych, jakim powinny odpowiadać bazy i stacje paliw płynnych, rurociągi przesyłowe dalekosiężne służące do transportu ropy naftowej i produktów naftowych i ich usytuowanie. 
Ostatnią przesłanką, która ma zastosowanie wyłącznie w postępowaniu zmierzającym do wydania decyzji o warunkach zabudowy, jest weryfikacja tak zwanej zasady dobrego sąsiedztwa. W omawianym postępowaniu lokalizacyjnym zasadą jest bowiem, że organ przeprowadza analizę zagospodarowania terenu znajdującego się w sąsiedztwie terenu objętego wnioskiem lokalizacyjnym w celu dostosowania planowanej zabudowy do cech istniejącego zagospodarowania i zabudowy. Istota tej zasady — jak wskazuje się w literaturze przedmiotu — sprowadza się do stworzenia czytelnego układu odniesienia do stanu istniejącej zabudowy, a $\mathrm{w}$ konsekwencji zachowania harmonii architektonicznej oraz funkcjonalnego charakteru określonego obszaru ${ }^{76}$. Dobrym sąsiedztwem jest więc takie zagospodarowanie terenu, którego funkcje, ale również parametry i cechy istniejącej zabudowy, mogą tworzyć harmonijną całość z zamierzeniem budowlanym określonym we wniosku lokalizacyjnym ${ }^{77}$. W praktyce weryfikacja właśnie tej przesłanki ustalenia warunków zabudowy budzi najwięcej wątpliwości po stronie zarówno organu, jak i stron postępowania, gdyż jej wynik dość często jest determinowany przyjętymi - na potrzeby przeprowadzenia omówionej poniżej analizy funkcji oraz cech zabudowy i zagospodarowania terenu — założeniami wstępnymi.

\section{Rozstrzygnięcie ujęte w wydawanych na zasadach ogólnych decyzjach ustalających warunki zabudowy i zagospodarowania terenu}

Pozytywna weryfikacja wskazanych powyżej przesłanek ustalenia warunków zabudowy i zagospodarowania terenu determinuje konieczność wydania decyzji pozytywnej, przy czym taka nie musi oznaczać rozstrzygnięcia pokrywającego się z treścią żądania inwestora. We wniosku o wydanie decyzji lokalizacyjnej inwestor określa bowiem nie tylko przedmiot i charakter inwestycji, ale również jej parametry, a w zakresie tych ostatnich organ jest związany zasadniczo tylko w postępowaniu zmierzającym do ustalenia lokalizacji inwestycji celu publicznego.

Związanie organu właściwego w przedmiocie ustalenia lokalizacji inwestycji celu publicznego wskazaniami wniosku w zakresie parametrów planowanego przedsięwzięcia oznacza konieczność ich powielenia w decyzji lokalizacyjnej

76 T. Bąkowski, [w:] W. Szwajdler, T. Bąkowski, Proces inwestycyjno-budowlany. Zagadnienia administracyjno-prawne, Toruń 2004, s. 91. Zob. też K. Małysa-Sulińska, Prawo do dobrego samorządu a tryby ustalania lokalizacji inwestycji, [w:] Prawo do dobrego samorzadu w kontekśsie realizacji zadań publicznych, red. M. Stec, K. Małysa-Sulińska, Warszawa 2021, s. $50 \mathrm{n}$.

77 Szerzej na temat wskazanej w art. 61 ust. 1 pkt 1 u.p.z.p. przesłanki wydania decyzji o warunkach zabudowy zob. K. Małysa-Sulińska, Administracyjnoprawne..., s. 104 n. 
w każdym przypadku, gdy brak jest przepisu prawa powszechnie obowiązującego, z którym wielkości określonych przez inwestora nie można byłoby pogodzić. W przypadku zaś kolizji wskazania ujętego we wniosku lokalizacyjnym z przepisem prawa powszechnie obowiązującego, organ jest zobligowany do dokonania korekty parametrów określonych przez inwestora w taki sposób, aby realizacja inwestycji była możliwa w świetle obowiązujących regulacji normatywnych ${ }^{78}$.

Inne rozwiązanie w tym zakresie ustawodawca przyjął natomiast w odniesieniu do inwestycji, której lokalizacja ustalana jest w formie decyzji o warunkach zabudowy. Parametry wskazane we wniosku o wydanie przedmiotowej decyzji lokalizacyjnej stanowią bowiem dla organu informację na temat oczekiwań inwestora $\mathrm{w}$ tym zakresie, a te są ustalane $\mathrm{w}$ toku postępowania $\mathrm{w}$ oparciu o wyniki przeprowadzonej analizy funkcji oraz cech zabudowy i zagospodarowania terenu. Celem przedmiotowej analizy jest weryfikacja przesłanek ustalenia warunków zabudowy, zaś jej efektem - wyznaczenie parametrów planowanej zabudowy, czyli: linii zabudowy, wskaźnika wielkości powierzchni zabudowy, szerokości elewacji frontowej, wysokości górnej krawędzi elewacji frontowej oraz geometrii dachu, które to wartości powinny mieć uzasadnienie w rozumowaniu opartym na wyliczeniach matematycznych ${ }^{79}$.

W związku z tym organ właściwy w przedmiocie ustalenia warunków zabudowy wyznacza wokół terenu objętego wnioskiem inwestora obszar analizowany i przeprowadza na nim wskazaną analizę funkcji oraz cech zabudowy i zagospodarowania terenu w zakresie warunków, o których mowa w art. 61 ust. 1-5 u.p.z.p. ${ }^{80}$ Granice tego obszaru wyznacza się w odległości nie mniejszej niż trzykrotna szerokość frontu działki objętej wnioskiem o ustalenie warunków zabudowy, ale nie mniejszej niż 50 metrów ${ }^{81}$, przy czym przez front działki należy rozumieć jej część przylegającą do drogi, z której odbywa się główny wjazd lub wejście na działkę ${ }^{82}$. Zaznaczenia wymaga przy tym, że z uwagi na cel analizy, którym jest ustalenie wielkości parametrów zabudowy już istnie-

78 Zob. np. art. 43 ust. 1 u.d.p., zgodnie z którym obiekty budowlane przy drodze ogólnodostępnej krajowej powinny być usytuowane od zewnętrznej krawędzi jezdni w odległości co najmniej $10 \mathrm{~m}$ w terenie zabudowy lub $25 \mathrm{~m}$ poza terenem zabudowy. W związku z tą regulacją żądanie inwestora o ustalenie lokalizacji inwestycji celu publicznego dla zabudowy, której realizacja jest planowana poza terenem zabudowy w odległości $20 \mathrm{~m}$ od zewnętrznej krawędzi jezdni drogi sklasyfikowanej jako ogólnodostępna krajowa zostanie skorygowane przez organ, który w decyzji lokalizacyjnej wyznaczy linię zabudowy w odległości $25 \mathrm{~m}$ od zewnętrznej krawędzi jezdni.

79 Zob. wyrok WSA w Krakowie z dnia 30 stycznia 2009 roku, sygn. I SA/Kr 1035/08, LEX nr 478695.

80 Zob. $\S 3$ ust. 1 rozporządzenia Ministra Infrastruktury z dnia 26 sierpnia 2003 roku w sprawie sposobu ustalania wymagań dotyczących nowej zabudowy i zagospodarowania terenu w przypadku braku miejscowego planu zagospodarowania przestrzennego, Dz.U. Nr 164, poz. 1588 (dalej: r.w.z.).

81 Zob. $\S 3$ ust. 2 r.w.z.

82 Zob. $\$ 2$ pkt 5 r.w.z. 
jącej na określonym obszarze, dla jej wyniku kwestią zasadniczą jest zakres terenu poddanego badaniu. W każdym bowiem przypadku, gdy organ analizuje obszar o zróżnicowanym obrazie architektonicznym, istotna jest ta okoliczność, czy przedmiot badania istniejącej zabudowy ogranicza się do terenu znajdującego się w bliskim sąsiedztwie planowanej inwestycji, czy też jego zakres jest szerszy. Parametry dla planowanego zamierzenia budowlanego organ wyznacza bowiem z uwzględnieniem wielkości, jakie są właściwe dla obiektów posadowionych na działkach sąsiednich ${ }^{83}$ albo obiektów znajdujących się w obszarze analizowanym $^{84}$. Mając na uwadze powyższe, wskazać należy, że brakuje definicji legalnej pojęcia działki sąsiedniej, co oznacza, iż termin ten może być interpretowany zarówno jako działka, która graniczy z terenem planowanej inwestycji, czyli styka się przynajmniej w jednym punkcie $\mathrm{z}$ obszarem objętym wnioskiem lokalizacyjnym ${ }^{85}$, jak i jako działka znajdująca się w okolicy tworzącej pewną urbanistyczną całość ${ }^{86}$. Istnieje przy tym wymóg ustawowy, aby przynajmniej jedna działka sąsiednia zabudowana w sposób pozwalający na określenie wymagań dotyczących nowej zabudowy oraz aby tereny planowanej inwestycji były dostępne z tej samej drogi publicznej (bezpośrednio, przez drogę wewnętrzną lub poprzez odpowiednią służebność drogową). To również stwarza możliwość podjęcia różnych rozstrzygnięć, a to dlatego, że działka sąsiednia lub teren planowanej inwestycji mogą być dostępne z kilku dróg publicznych, ale też dostępność ta może być potencjalna, a nie rzeczywista. Jednocześnie przepisy nie stanowią żadnych wymogów względem zabudowy, która może stanowić podstawę do ustalenia warunków zabudowy, w tym także w zakresie jej legalności czy też — jeśli budowa nie została zakończona — zaawansowania wykonanych prac budowlanych. Taka sytuacja może prowadzić do odmiennych ustaleń orzeczniczych w toku postępowania lokalizacyjnego ${ }^{87}$.

${ }^{83}$ Zob. $\S 4$ ust. 1 i $§ 7$ ust. 1 r.w.z. (szerzej na ten temat zob. K. Małysa-Sulińska, Administracyjnoprawne..., s. 114 n.).

84 Zob. $\S 5$ ust. $1, \S 6$ ust. $1, \S 7$ ust. 3 , $\S 8$ r.w.z. (szerzej na ten temat zob. ibidem, s. 116 n.).

85 Zob. M. Szewczyk, W sprawie interpretacji pojęcia ,dzialka sasiednia” (użytego w przepisie art. 61 ust. 1 pkt 1 ustawy z dnia 27 marca 2003 r. o planowaniu i zagospodarowaniu przestrzennym oraz $w$ przepisach rozporzadzenia Ministra Infrastruktury z dnia 26 sierpnia $2003 \mathrm{r}$. w sprawie sposobu ustalania wymagań dotyczacych nowej zabudowy i zagospodarowania terenu w przypadku braku miejscowego planu zagospodarowania przestrzennego), „Casus” 2005, nr 35, s. 8.

${ }^{86}$ Zob. D.R. Kijowski, Zabudowa nieruchomości na terenach nie objętych miejscowym planem zagospodarowania przestrzennego, „Casus” 2005, nr 37, s. 13; K. Małysa-Sulińska, Dobre sąsiedztwo jako przesłanka wydania decyzji o warunkach zabudowy, „Casus” 2009, nr 51, s. 7; Planowanie..., s. 511.

87 Szerzej na ten temat zob. K. Małysa-Sulińska, Swoboda organów administracji publicznej w określaniu przeznaczenia i sposobu zagospodarowania terenu, „Samorząd Terytorialny” 2015, nr 7-8, s. 19 n. 
Analiza wskazanych powyżej regulacji normatywnych odnoszących się do decyzji o lokalizacji inwestycji celu publicznego wskazuje, że ustawodawca przyjął rozwiązanie, zgodnie z którym organ gminy procedujący w tym przedmiocie jest zobligowany - po przeprowadzeniu weryfikacji przesłanek determinujących możliwość wydania przedmiotowej decyzji — do podjęcia rozstrzygnięcia określonej treści i nie posiada żadnego luzu decyzyjnego w tym zakresie. Stwierdzenie bowiem przez organ, że spełnione są przesłanki ustalenia lokalizacji inwestycji celu publicznego oznacza konieczność wydania decyzji pozytywnej dla inwestycji w kształcie określonym przez inwestora we wniosku, względnie — jeśli jest to możliwe - zmodyfikowanym poprzez dostosowanie go do wymogów stanowionych przez przepisy prawa powszechnie obowiązującego. Ustalenie zaś przez organ, że przesłanki wydania przedmiotowej decyzji nie zachodzą, oznacza brak możliwości wydania decyzji o ustaleniu lokalizacji inwestycji celu publicznego.

Nieco inne rozwiązanie ustawodawca przyjął w odniesieniu do decyzji o warunkach zabudowy. Wprawdzie możliwość pozytywnego ustosunkowania się przez organ do żądania inwestora wskazanego we wniosku lokalizacyjnym jest również — tak jak w przypadku wskazanej powyżej decyzji o ustaleniu lokalizacji inwestycji celu publicznego - determinowana spełnieniem przesłanek wydania przedmiotowej decyzji lokalizacyjnej, ale ich spełnienie nie przesądza o treści rozstrzygnięcia $\mathrm{w}$ zakresie parametrów wnioskowanego przedsięwzięcia budowlanego. W odniesieniu do tego rodzaju decyzji ustalającej warunki zabudowy i zagospodarowania terenu przyjęto bowiem rozwiązanie, w myśl którego parametry planowanej inwestycji wyznaczane są przez organ właściwy w sprawie w oparciu o wynik przeprowadzonej analizy funkcji oraz cech zabudowy i zagospodarowania terenu. Przy tym przepisy r.w.z. zasadniczo dopuszczają ich wyznaczenie $\mathrm{z}$ pominięciem wielkości uzyskanych $\mathrm{w}$ drodze matematycznej analizy ${ }^{88}$, z zastrzeżeniem, że takie ich wyznaczenie znajduje uzasadnienie w wynikach przeprowadzonej analizy ${ }^{89}$. To zaś oznacza, że organ gminy właściwy w przedmiocie wydania decyzji o warunkach zabudowy posiada luz decyzyjny nie tylko w zakresie sposobu wyznaczenia obszaru poddanego analizie, co wskazano powyżej, ale również w zakresie określenia parametrów przyszłej zabudowy.

88 Zob. $\S 4$ ust. 4 r.u.w., $\S 5$ ust. 2 r.u.w., $§ 6$ ust. 2 r.u.w., $§ 7$ ust. 4 r.u.w. (szerzej na ten temat zob. K. Małysa-Sulińska, Administracyjnoprawne..., s. 115 n.).

89 Informacje ujęte w analizie funkcji oraz cech zabudowy i zagospodarowania terenu powinny stanowić bowiem istotny element wyjaśniający i uzasadniający podstawowe motywy rozstrzygnięcia w sprawie określenia sposobów zagospodarowania i warunków zabudowy terenu (zob. wyrok WSA we Wrocławiu z dnia 16 kwietnia 2009 roku, sygn. II SA/Wr 458/08, LEX nr 550308. Por. także wyrok WSA w Krakowie z dnia 23 października 2007 roku, sygn. II SA/Kr 289/05, LEX nr 394841; wyrok WSA w Warszawie z dnia 23 listopada 2007 roku, sygn. IV SA/Wa 1601/06, LEX nr 424613; wyrok WSA w Białymstoku z dnia 3 czerwca 2008 roku, sygn. II SA/Bk 183/08, LEX nr 499844). 


\section{Podsumowanie i wnioski}

W świetle regulacji normatywnych przedstawionych w niniejszym artykule nie może budzić wątpliwości, iż ustawodawca szeroko zakreślił zakres kompetencji organów gminy w przedmiocie określania przeznaczania i warunków zabudowy terenu. W aktualnym stanie prawnym zasadą jest bowiem, że rozstrzygnięcia w tym zakresie zapadają w trybie przepisów ogólnych u.p.z.p. i przybierają postać albo - uchwalanego zasadniczo przez radę gminy - miejscowego planu zagospodarowania przestrzennego, albo - wydawanej zazwyczaj przez wójta (burmistrza lub prezydenta miasta) - decyzji ustalającej warunki zabudowy i zagospodarowania terenu, czyli decyzji o lokalizacji inwestycji celu publicznego lub decyzji o warunkach zabudowy.

Trzeba jednak zauważyć, że decydowania o przeznaczeniu terenu i warunkach jego zabudowy ustawodawca nie pozostawił do wyłącznej kompetencji organów gminy, stanowiąc, iż legitymowane w tym zakresie - w przypadkach określonych wprost w przepisach prawa - mogą być także inne organy, w tym będący organem administracji rządowej wojewoda. Zaznaczenia wymaga również, że — zgodnie z rozwiązaniem przyjętym przez ustawodawcę — organy gminy, podejmując rozstrzygnięcia w ramach władztwa planistycznego, zobligowane są do współdziałania $\mathrm{z}$ innymi organami, co w pewnym zakresie ogranicza ich samodzielność w tym zakresie. Nadto — mając na uwadze obowiązujące regulacje u.p.z.p. w zakresie ustalania warunków zabudowy i zagospodarowania terenu w formie decyzji lokalizacyjnej — wskazać trzeba, że organy gminy podejmują rozstrzygnięcia $\mathrm{w}$ tym zakresie nie dysponując $\mathrm{w}$ istocie swobodą planistyczną, a działając jedynie w ramach zakreślonego przez prawodawcę luzu decyzyjnego.

\section{Bibliografia}

Bąkowski T., O skali normatywnej $i$ wadze teoretycznej specustaw inwestycyjno-budowlanych oraz o motywach ich stanowienia, [w:] Specustawy inwestycyjno-budowlane, red. T. Bąkowski, Gdańsk 2020.

Bielecki L., Drogi publiczne, [w:] Prawo administracyjne — część szczegółowa, red. P. Ruczkowski, t. 2, Warszawa 2011.

Bigo T., Zwiazki publiczno-prawne w świetle ustawodawstw polskiego, Warszawa 1928.

Kijowski D.R., Zabudowa nieruchomości na terenach nieobjętych miejscowym planem zagospodarowania przestrzennego, „Casus” 2005, nr 37.

Leoński Z., Szewczyk M., Kruś M., Prawo zagospodarowania przestrzeni, Warszawa 2019.

Małysa-Sulińska K., Administracyjnoprawne aspekty inwestycji budowlanych, Warszawa 2012.

Małysa-Sulińska K., Dobre sasiedztwo jako przestanka wydania decyzji o warunkach zabudowy, „Casus” 2009, nr 51. 
Małysa-Sulińska K., Mnogość trybów ustalania lokalizacji inwestycji mieszkaniowej i inwestycji jej towarzyszacych jako konsekwencja wejścia w życie przepisów specustawy mieszkaniowej, [w:] Specustawy inwestycyjno-budowlane, red. T. Bąkowski, Gdańsk 2020.

Małysa-Sulińska K., Normy ksztattujace tad przestrzenny, Warszawa 2008.

Małysa-Sulińska K., Organ właściwy w sprawach inwestycyjno-budowlanych prowadzonych w oparciu o regulacje szczególne ujęte w specustawach inwestycyjnych, [w:] System administracyjnego prawa procesowego, red. A. Matan, G. Łaszczyca, t. 4. Postępowania autonomiczne i szczególne. Postępowania niejurysdykcyjne, red. tomu A. Matan, Warszawa 2021.

Małysa-Sulińska K., Postępowania w sprawach inwestycyjno-budowlanych prowadzone w oparciu o regulacje szczególne ujęte w przepisach specustaw inwestycyjnych, [w:] System administracyjnego prawa procesowego, red. A. Matan, G. Łaszczyca, t. 4. Postępowania autonomiczne i szczególne. Postępowania niejurysdykcyjne, red. tomu A. Matan, Warszawa 2021.

Małysa-Sulińska K., Prawo do dobrego samorzadu a tryby ustalania lokalizacji inwestycji, [w:] Prawo do dobrego samorzadu w kontekście realizacji zadań publicznych, red. M. Stec, K. Małysa-Sulińska, Warszawa 2021.

Małysa-Sulińska K., Ramowe studium uwarunkowań i kierunków zagospodarowania przestrzennego zwiazku metropolitalnego a władztwo planistyczne gminy, „Ruch Prawniczy, Ekonomiczny i Socjologiczny" 2017, nr 3.

Małysa-Sulińska K., Rozstrzygnięcia ograniczające samodzielność planistyczna gminy w toku sporządzania miejscowego planu zagospodarowania przestrzennego, [w:] Nadzór nad samorzadem a granice jego samodzielności, red. M. Stec, M. Mączyński, Warszawa 2011.

Małysa-Sulińska K., Stosowanie przepisów regulujących sposób przeprowadzania analizy funkcji oraz cech zabudowy i zagospodarowania terenu a rozpraszanie $i$ koncentracja zabudowy, [w:] Prawne problemy rozpraszania i koncentracji zabudowy, red. T. Bąkowski, Gdańsk 2018.

Małysa-Sulińska K., Swoboda organów administracji publicznej w określaniu przeznaczenia i sposobu zagospodarowania terenu, „Samorząd Terytorialny” 2015, $\mathrm{nr} 7-8$.

Małysa-Sulińska K., Ustalenia czynione w toku postępowań w sprawach inwestycyjno-budowlanych prowadzonych w oparciu o regulacje szczególne ujęte w przepisach specustaw inwestycyjnych, [w:] System administracyjnego prawa procesowego, red. A. Matan, G. Łaszczyca, t. 4. Postepowania autonomiczne i szczególne. Postępowania niejurysdykcyjne, red. tomu A. Matan, Warszawa 2021.

Małysa-Sulińska K., Zakres przedmiotowy przedsięwzięć, dla których warunki zabudowy i zagospodarowania terenu określane sa w formie decyzji o ustaleniu lokalizacji inwestycji celu publicznego, „Casus” 2009, nr 53.

Planowanie i zagospodarowanie przestrzenne. Komentarz, red. Z. Niewiadomski, K. Jaroszyński, K. Kucharski, A. Szmytt, Ł. Złakowski, Warszawa 2021.

Szewczyk M., Lokalizacja inwestycji publicznych w świetle nowej ustawy o planowaniu i zagospodarowaniu przestrzennym, „Casus” 2003, nr 28.

Szewczyk M., W sprawie interpretacji pojęcia ,działka sąsiednia” (użytego w przepisie art. 61 ust. 1 pkt 1 ustawy z dnia 27 marca 2003 r. o planowaniu i zagospodarowaniu przestrzennym oraz w przepisach rozporządzenia Ministra Infrastruktury z dnia 26 sierpnia $2003 \mathrm{r}$. w sprawie sposobu ustalania wymagań dotyczacych nowej zabudowy i zagospodarowania terenu w przypadku braku miejscowego planu zagospodarowania przestrzennego), „Casus” 2005, nr 35.

Szwajdler W., Bąkowski T., Proces inwestycyjno-budowlany. Zagadnienia administracyjno-prawne, Toruń 2004.

Ustawa o planowaniu i zagospodarowaniu przestrzennym. Komentarz, red. M. Wierzbowski, A. Plucińska-Filipowicz, Warszawa 2016.

Zalas G., Warunki zabudowy i zagospodarowania terenu — nowe rozwiazania w zakresie realizacji inwestycji, „Casus” 2004, nr 31.

Prawo 333, 2021

(C) for this edition by CNS 


\title{
Planning Powers of a Municipality vs. Specifying the Method and Conditions of Developing Land
}

\begin{abstract}
Summary
This article addresses the municipality's planning powers, which are not unlimited and should not be understood as full freedom of the municipality to specify the intended purpose of land and the rules of its development. This is because the lawmakers did not leave the decision on the intended purpose of land and the conditions for its development to the exclusive competence of the municipal authorities, but gave other bodies of public administration powers in this respect. Furthermore, when making decisions within the framework of the planning powers, the municipal authorities have been obliged by the lawmakers to cooperate with other authorities. An analysis of the normative solutions regarding location decisions also suggests that, when making such decisions, municipal authorities do not essentially have planning freedom, but act solely within the discretionary powers specified by the lawmakers.
\end{abstract}

Keywords: planning powers of a municipality, specification of the method and conditions of developing land, decision on the setting of a location for a public service investment, planning permission. 